\title{
Practicing and Factors Infuencing the Effective Implementation of Strategic Information Systems Planning in Public Agency
}

(Amalan dan Faktor yang Mempengaruhi Keberkesanan Pelaksanaan Perancangan Strategik Sistem Maklumat di Agensi Awam)

\author{
Sukhaila Angsor \\ (Malaysian Royal Custom Department) \\ Maryati Mohd Yusof
}

(Faculty of Information Science and Technology, Universiti Kebangsaan Malaysia)

\begin{abstract}
Strategic Information Systems Planning (SISP) guided organization in achieving its target. The importance of SISP increases proportionately with the uncertainty of business requirements. Failures in implementing SISP may affect organizational service delivery and reputation. This paper discusses on the evaluation of the practice and influencing factors of SISP implementation in a public sector. The Human Organization Technology-fit framework was used to evaluate the effectiveness of SISP from human, organization and technology perspectives. A qualitative case study was conducted using interview and document analysis method. The study identified 25 influencing factors of SISP implementation including knowledge and expertise, stakeholder engagement; governance, top management support, financial allocation and infrastructure capabilities. These influencing factors can guide other agencies to identify the risks of SISP implementation at an early stage; subsequently, mitigation plan can be developed to minimize the risk.
\end{abstract}

Keywords: Effectiveness; evaluation; information systems planning; strategic; practice

\section{ABSTRAK}

Perancangan strategik sistem maklumat (Strategic Information Systems Planning) (SISP) digunakan sebagai garis panduan untuk mencapai hala tuju organisasi. Kepentingan SISP meningkat sejajar dengan peningkatan keperluan bisnes yang tidak menentu. Kegagalan organisasi dalam melaksanakan SISP boleh memberi kesan terhadap penyampaian perkhidmatan dan juga reputasi organisasi. Kertas ini membincang penilaian amalan dan faktor yang mempengaruhi pelaksanaan SISP di agensi kerajaan. Kerangka Human Organization Technology-fit (HOT-fit) yang terdiri daripada tiga faktor iaitu manusia, organisasi dan teknologi diguna untuk menilai keberkesanan SISP. Kajian kes dijalankan melalui temu bual dan analisis kandungan dokumen. Dapatan menunjukkan 25 faktor yang mempengaruhi pelaksanaan SISP termasuk pengetahuan dan kepakaran, penglibatan, tadbir urus, sokongan pengurusan atasan, peruntukan kewangan dan keupayaan infrastruktur. Faktor ini boleh dijadikan panduan kepada agensi lain supaya risiko pelaksanaan SISP dapat dikenal pasti di peringkat awal dan perancangan mitigasi dapat dibina bagi meminimum risiko.

Kata kunci: Amalan; keberkesanan; penilaian; perancangan sistem maklumat; strategik 


\section{INTRODUCTION}

Strategic Information Systems Planning (SISP) is a systematic process to evaluate business capability, whilst the strength, weakness, opportunity and threat analysis can be used to identify organisational position and potential ( Turban, Pollard \& Wood 2018). An organisation must develop SISP to realise its business vision and mision through strategic direction and information communication and technology (ICT) action plan; the latter serves to increase organisational performance and competitiveness by maximising ICT (Al-Ammary et al. 2019; Ali, Crump \& Sudin 2014; Haron, Sabri \& Zolkarnain 2013). However, SISP's main problems include management team's non compliance and low prioritisation of the planning process (Kelvin, Oghenetega \& Jackson 2012); overfocus on certain ICT aspect and neglecting others; exclusion of uncertain environmental changes during planning; and low involvement of top and middle management owing to conflicting commitments (Bermejo \& Zambalde 2014; Manoharan, Melitski \& Bromberg 2015; Zubovic, Pita \& Khan 2014). These problems can affect the input quality of the planning process that can subsequently affect the effectiveness of SISP implementation. Moreover, limited analysis of organisational environment can also increase the failure rate of SISP implementation (Manoharan et al. 2015). The effectiveness of SISP implementation requires assessment by measuring the achievement level of organisational objective and how an organisation identifies and addresses its weaknesses. SISP implementation failure is a waste of information systems' (IS) resources given its overwhelming cost. The understanding of factors influencing SISP effectiveness can shed some light on why an organisation can increase its performance. The study discusses findings in a case study on the evaluation pertinent to practice, effectiveness and factors influencing SISP implementation at a public sector agency.

\section{LITERATURE REVIEW}

SISP is a process that identifies how ICT/ IS can support an organisation in implementing its business objectives (Lederer \& Salmela 1996; Mirchandani \& Lederer 2014). In the globalisation era, SISP importance increased proportionately with pressure in the business environment (Alamri et al. 2016). SISP is essential in increasing its competitiveness, productivity and performance; improving or changing management approach and creating new business opportunity through ICT use (Pita, Cheong \& Corbitt 2014). The importance of SISP can be seen from studies related to its process, success, methodology, strategic alignment, approach and implementation.

\section{SISP IMPLEMENTATION}

The effectiveness of SISP implementation refers to an organisation's capability to ensure that IS strategic plan is executed (Mohdzaher \& Ward 2007; Zubovic et al. 2014). The implementation phase is critical, particularly for an organisation surrounded in an uncertain environment. Okumus (2003) stated that more than 70 percent of organisations failed to implement their strategic initiative plan owing to the managers and supervisors' inability to execute the strategy using a specific model as their guide. The integration process between IT and business is crucial during the SISP implementation process as it is related to business performance. Organisational improvement is attributable to accurate decision and action instead of the plan alone. SISP implementation can fail in many ways, including the absence of planning and plans, planning without implementation, and implementation with no effect on an organisation. SISP implementation failure is not limited to these four situations; it is also caused by three other main factors, namely, leadership, involvement and motivation (Klag \& 
Langley 2014) that lead to an organisation's incapacity to change (Arvidsson, Holmström \& Lyytinen 2014).

An organisation uses IT to measure organisational performance strategically (Klag \& Langley 2014). Therefore, the alignment of IT and business requires continous measurement by individuals who are both IT and business savvy (Wahyudin \& Hasibuan 2015). Harun and Hashim (2012) identified 11 main problems in SISP implementation among 55 Malaysian companies, namely, financial allocation constraint, incomplete implementation plan, lack of skill and knowledge, low commitment, no motivation to initiate SISP, lack of top management involvement, time constraint, poor communication, misalignment of SISP with business objective, failure to identify business environment need and exclusion of IS management in the corporate planning process. We identified 18 influencing factors of SISP from the literature (Table 1).

TABLE 1. Factors Influencing SISP

\begin{tabular}{|c|c|c|c|}
\hline & Factor & Description & Reference \\
\hline 1 & Environment & $\begin{array}{l}\text { Understanding of business and IT trend; } \\
\text { uncertain environment; IT and business } \\
\text { change }\end{array}$ & $\begin{array}{l}\text { Al-Aboud (2011); Alamri et al. } \\
\text { (2016); Amrollahi, Ghapanchi, } \\
\text { Talaei-Khoei (2013); Harun \& } \\
\text { Hashim (2012); Yang, Pita \& } \\
\text { Singh (2013); Hoque, Hossin \& } \\
\text { Khan (2017) }\end{array}$ \\
\hline 2 & $\begin{array}{l}\text { Organisational } \\
\text { commitment }\end{array}$ & Stakeholder commitment & $\begin{array}{l}\text { Khani (2010); } \\
\text { Harun \& Hashim (2012); }\end{array}$ \\
\hline 3 & Leadership & Team leader/ manager capability & $\begin{array}{l}\text { Hoque et al. (2017); Ismail et } \\
\text { al.(2007); Klag \& Langley } \\
\text { (2014) }\end{array}$ \\
\hline 4 & Motivation & $\begin{array}{l}\text { Motivation to implement ICT project/ } \\
\text { programme }\end{array}$ & $\begin{array}{l}\text { Harun \& Hashim (2012); Hoque } \\
\text { et al. (2017) (Klag \& Langley } \\
\text { (2014) }\end{array}$ \\
\hline 5 & Alignment & Business-IT Alignment & $\begin{array}{l}\text { Harun \& Hashim (2012); Ismail } \\
\text { et al.(2007); Pita et al. } \\
\text { (2014)Yang et al. (2013); }\end{array}$ \\
\hline 6 & Training & $\begin{array}{l}\text { Training requirement for IT development } \\
\text { and IT implementation }\end{array}$ & $\begin{array}{l}\text { Hoque et al. (2017)Ismail et } \\
\text { al.(2007); }\end{array}$ \\
\hline 7 & IS service support & Technical support & Ismail et al. (2007) \\
\hline 8 & $\begin{array}{l}\text { Skill and } \\
\text { knowledge }\end{array}$ & $\begin{array}{l}\text { Staff skill and knowledge to implement } \\
\text { SISP }\end{array}$ & $\begin{array}{l}\text { Harun \& Hashim (2012); Hoque } \\
\text { et al. (2017);Harun \& Hashim } \\
\text { (2017); Ismail et al.(2007); }\end{array}$ \\
\hline 9 & $\begin{array}{l}\text { Organisational } \\
\text { readiness }\end{array}$ & $\begin{array}{l}\text { Organisational readiness to implement } \\
\text { planning }\end{array}$ & Harun \& Hashim (2012) \\
\hline 10 & Time & Time required to implement planning & $\begin{array}{l}\text { Harun \& Hashim (2012); } \\
\text { Hoque et al. (2017) }\end{array}$ \\
\hline 11 & $\begin{array}{l}\text { Environmental } \\
\text { analysis }\end{array}$ & $\begin{array}{l}\text { Analysis of strength, weakness, threat, } \\
\text { opportunity, environment and technology }\end{array}$ & $\begin{array}{l}\text { Amrollahi et al. (2013) } \\
\text { Hoque et al. (2017) }\end{array}$ \\
\hline 12 & $\begin{array}{l}\text { Involvement and } \\
\text { top management } \\
\text { support }\end{array}$ & $\begin{array}{l}\text { Involvement from team, top management, } \\
\text { and stakeholder }\end{array}$ & $\begin{array}{l}\text { Harun \& Hashim (2012); Khani } \\
\text { (2010); Klag \& Langley } \\
\text { (2014);Yang et al.(2013) }\end{array}$ \\
\hline 13 & $\begin{array}{l}\text { Communication } \\
\text { and sharing }\end{array}$ & $\begin{array}{l}\text { Knowledge sharing and communication } \\
\text { between business and IT }\end{array}$ & $\begin{array}{l}\text { Harun \& Hashim (2012); Yang } \\
\text { et al. (2013) }\end{array}$ \\
\hline 14 & Resource allocation & Human, financial and IT allocation & $\begin{array}{l}\text { Harun \& Hashim (2012); Hoque } \\
\text { et al. (2017); Yang et al. (2013) }\end{array}$ \\
\hline 15 & Education & $\begin{array}{l}\text { Enhancement of application, skill and ICT } \\
\text { staff competency }\end{array}$ & Yang et al. (2013) \\
\hline 16 & $\begin{array}{l}\text { Organisation-- } \\
\text { supplier sharing }\end{array}$ & Knowledge sharing & Yang et al. (2013) \\
\hline 17 & SISP centralisation & Centralised SISP implementation & Amrollahi et al. (2013) \\
\hline
\end{tabular}




\begin{tabular}{|c|c|c|c|}
\hline 18 & $\begin{array}{l}\text { Implementation } \\
\text { strategy }\end{array}$ & Planning for SISP implementation & $\begin{array}{l}\text { Amrollahi et al.(2013); } \\
\text { Hoque et al. (2017) }\end{array}$ \\
\hline
\end{tabular}

SISP success can be measured through the objective achievement level and its impact on an organisation. Success indicators are referred as alignment, analysis, collaboration and capability enhancement (Segars \& Grover 1998; Al-Aboud 2011; Pita et al. 2014). According to Yang, Pita and Khan (2013), SISP success is measured from three dimensions: a) dynamic capability, b) IS efficiency and c) flexible IT infrastructure (Table 2).

TABLE 2. SISP Success indicator

\begin{tabular}{|c|c|c|}
\hline Indicator & Description & References \\
\hline Alignment & $\begin{array}{l}\text { Relationship between IS strategy and } \\
\text { business in achieving organisational } \\
\text { objective }\end{array}$ & $\begin{array}{l}\text { Alamri et al. (2016) } \\
\text { Al-Aboud (2011); } \\
\text { Pita et al.(2014) }\end{array}$ \\
\hline Analysis & $\begin{array}{l}\text { Comprehensive analysis of current } \\
\text { business and IT aspects }\end{array}$ & Segars \& Grover (1998a) \\
\hline Collaboration & $\begin{array}{l}\text { Collaboration among team, user and } \\
\text { stakeholder }\end{array}$ & \\
\hline Capability improvement & Improved IS change and use & \\
\hline Dynamic capability & $\begin{array}{l}\text { Organisational capability to change } \\
\text { according to environment }\end{array}$ & Yang et al. (2013) \\
\hline IS effeciency & Efficient IS & \\
\hline Flexible IT infrastructure & $\begin{array}{l}\text { Preparing infrastructure and } \\
\text { acquiring skill according to market } \\
\text { needs }\end{array}$ & \\
\hline
\end{tabular}

\section{INFORMATION SYSTEMS AND BUSINESS EVALUATION}

Evaluation refers to an ongoing process of justifying the organisational effectiveness in implementing its planned activity and achieving the targetted objective. IS evaluation served to understand system performance and improve system based on an effective method and technique (Yusof, Paul \& Stergioulas 2006). We analysed two evaluation frameworks, namely, Balance Scorecard (BSC) and Human Organisation Technology-fit (HOT-fit) (Yusof et al. 2008; Yusof 2015) to identify the level of SISP implementation as a basis for enhancing the approach to IS strategy planning.

Kaplan and Norton (1996) introduced BSC as a method for measuring organisational performance in management perspective (Figure 1). BSC is linked to strategic implementation by briefing the executive on main success factors, thereby possibly aligning the latter with business operation. BSC is applied in measuring performance, strategic management and project management. BSC strength lies in its flexibility and adaptability as a strategic map that can be easily understood to provide a holistic performance prospect (Awadallah \& Alam 2015; Turban et al. 2018). BSC provides multi-perspective information on strategic implementation planning and can be coordinated flexibly. Owing to its market orientation, BSC emphasised more on the financial aspect in measuring success performance than the other three measurement perspectives (Turban et al. 2018).

BSC popularity is attributed to its flexible features that can be adapted to organisational nature, assistance in ensuring coordination and alignment between financial and non-financial aspects and support in identifying and measuring a trigger to specific value that influences performance (Murby \& Gould 2005). Despite its popularity, not all organisations successfully used it. Approximately more than half of the American manufacturing companies applied BSC, but the failure is reported to be up by 50 to 70 percent (Allio 2012). Ineffective application of $\mathrm{BSC}$ in measuring performance is attributable to 
a) Poor scrutiny of the relationship between strategy and performance measure,

b) Absence of formal cause-effect model or strategy map,

c) Absence of non-financial measures in establishing financial performance.

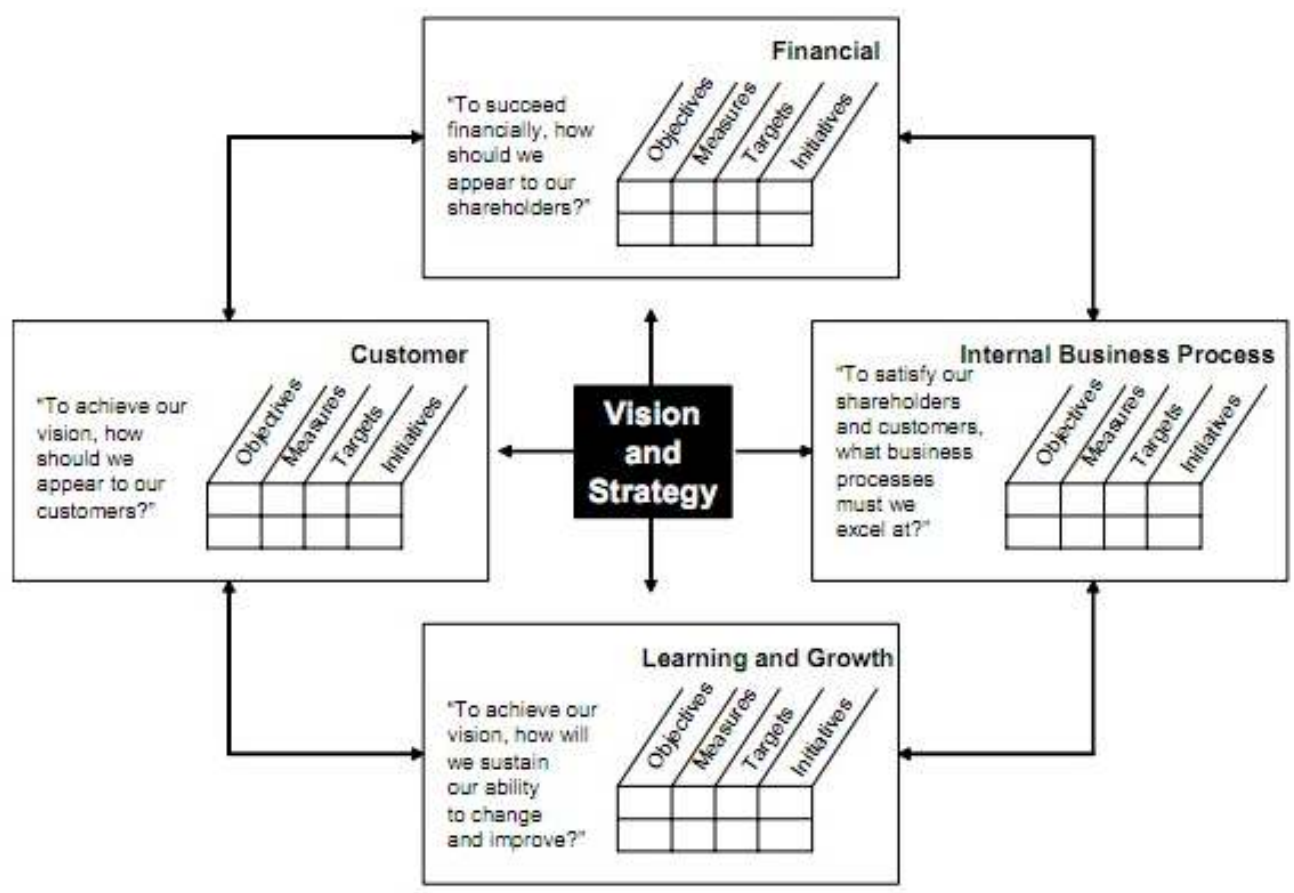

FIGURE 1. Balanced score card

(Source: Kaplan \& Norton 1996)

By contrast, HOT-fit framework is built on the IS Success Model and IT-Organisation Fit Model (Yusof et al. 2008; Yusof 2015) (Figure 2). The framework emphasised on three interrelated factors, namely, human, organisation and technology. HOT-fit was initially used to evaluate Health Information Systems and later in various domains. The framework was updated, consequently improving its comprehensiveness and allowing an effective evaluation, including that on complex IS. Evaluation outcomes can yield an improvement of process, techniques and IS planning method. Yusof et al. (2008) specified measure elements of the HOT factors beneficial to both individuals and organisations from technology use.

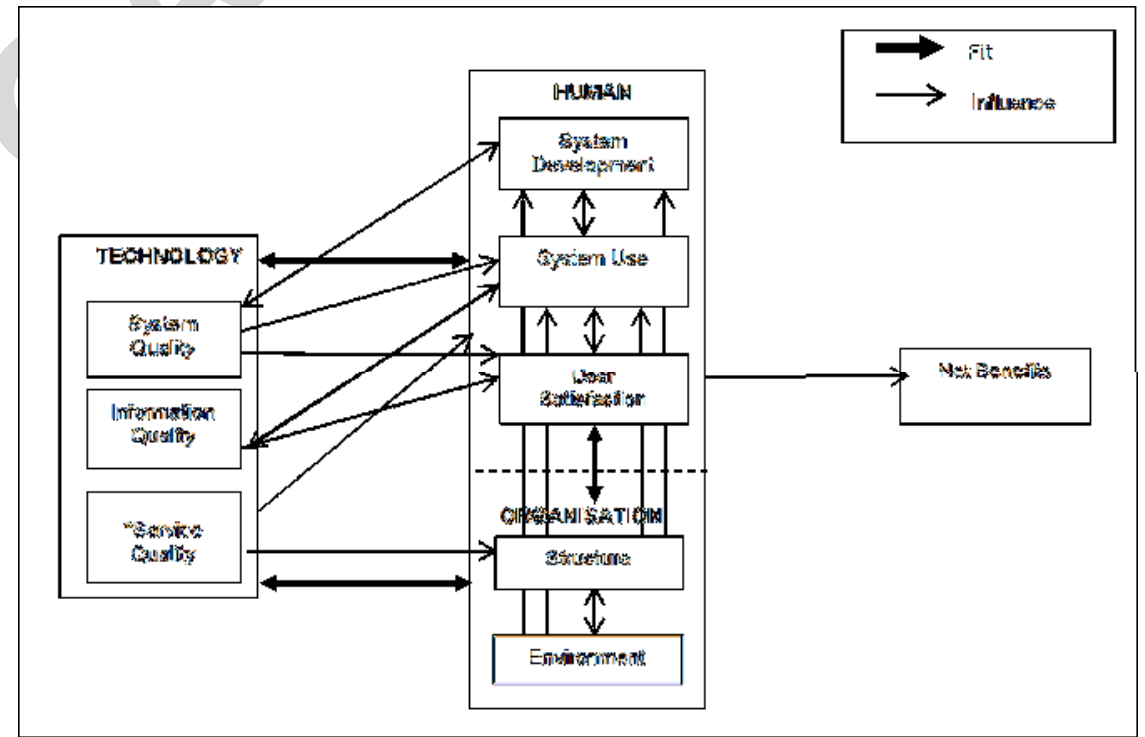

FIGURE 2. HOT-fit framework (adapted from Yusof [2015]) 
Technology factor consists of three dimensions, namely, system, information and service qualities. Human factor consists of three dimensions, namely, system development, system use and user satisfaction; whilst two dimensions under the organisation factor are structure and environment. All dimensions are interrelated, influence one another, important in evaluating IS effectiveness and contribute to net benefits. HOT-fit is an evaluation framework that particularly focuses on IS components and its environment. By contrast, BSC specifically focuses on the long-term financial factors related to profit, asset return and increased income. Table 3 lists the difference between HOT-fit and BSC.

TABLE 3. Comparison of evaluation frameworks

\begin{tabular}{llll}
\hline Framework & Function & $\begin{array}{l}\text { Element/ Evaluation } \\
\text { perspective }\end{array}$ & Strength \\
\hline HOT-fit & $\begin{array}{l}\text { Evaluates IS } \\
\text { effectiveness } \\
\text { and } \\
\text { performance }\end{array}$ & $\begin{array}{l}\text { Human } \\
\text { Organisation } \\
\text { Technology }\end{array}$ & $\begin{array}{l}\text { Comprehensive evaluation element. } \\
\text { Elements are interrelated and } \\
\text { subsequently affect organisation (Net } \\
\text { Benefits) }\end{array}$ \\
BSC & $\begin{array}{l}\text { Measures project } \\
\text { management } \\
\text { performance }\end{array}$ & $\begin{array}{l}\text { Finance } \\
\text { Customer } \\
\text { Stakeholder } \\
\text { Education and development }\end{array}$ & Focuses on IT/IS \\
& & & $\begin{array}{l}\text { Focuses more on financial perspective } \\
\text { than with the other three perspectives. }\end{array}$ \\
\hline
\end{tabular}

Based on the HOT-fit and BSC framework, HOT-fit featured a closely similar evaluation aspect reviewed in the SISP literature. Based on its comprehensive factor and dimension measure, the framework can evaluate performance, effectiveness and IS impact (Yusof, Stergioulas \& Zugic 2007) on organisational environment. Factors influencing SISP implementation were identified from the literature (see Table 1) and adapted to the HOT-fit framework according to human, organisational and technological aspects (Table 4). The mapping of SISP and HOT-fit framework identified six overlapping factors marked with * in Table 4 and subsequently used to guide the case study evaluation.

\section{METHOD}

The qualitative case study was conducted at a Malaysian public sector known as State X Secretarial Office (SXSSO) as the organisation had implemented SISP twice from 2011 to 2015 and from 2016 to 2020 . SXSSO is responsible for ICT development and progress at state $\mathrm{X}$ agencies. Data were gathered in two months, starting on 6 June 2017, through interviews and document analysis techniques. One-on-one and group semi-structured interviews were conducted with 11 informants: five from top and middle management teams, four among implementers and users, and two individuals; with over a total duration of $8 \mathrm{~h}$ and $49 \mathrm{~min}$. Table 5 shows the informant list. Documents were analysed from SXSSO ICT Strategic Plan 2011-2015, Annual report for 2012 and SXSSO 2013 and Strategic SXSSO ICT Plan Implementation Achievement Report 2011-2015. Data were transcribed and analysed systematically on the basis of themes related to human, organisational and technological factors. 
TABLE 4. Mapping of SISP implementation factor to HOT-fit framework

\begin{tabular}{|c|c|c|}
\hline FACTOR & DIMENSION/ ELEMENT & DESCRIPTION \\
\hline HUMAN & $\begin{array}{l}\text { Involvement and commitment } \\
\text { Knowledge and skill } \\
\text { Education development } \\
\text { Implementation strategy } \\
\text { *IT-business relationship } \\
\text { *Motivation } \\
\text { *Training }\end{array}$ & $\begin{array}{l}\text { Team, top management and stakeholder involvement } \\
\text { Staff skill in ICT project implementation } \\
\text { Enhanced staff capability in ICT } \\
\text { Strategy used to ensure that SISP can be implemented } \\
\text { Relationship betwen business and IT staff } \\
\text { Staff motivation to initiate SISP } \\
\text { Training for IT development and implementation }\end{array}$ \\
\hline ORGANISATION & $\begin{array}{l}\text { Organisational readiness } \\
\text { * top management support/commitment } \\
\text { *Leadership } \\
\text { IT and business change } \\
\text { Centralised/ distributed IS planning } \\
\text { *Understanding of business and IT trend } \\
\text { *Communication and knowledge sharing } \\
\text { between business and IT sector } \\
\text { *Financial resources } \\
\text { Organisational commitment } \\
\text { Time }\end{array}$ & $\begin{array}{l}\text { TRUCTURE } \\
\text { Organisational readiness to implement planning. } \\
\text { Top management support in SISP implementation } \\
\text { Leadership approach/ Team leader/ manager } \\
\text { capability } \\
\text { Uncertain environment, policy and business change } \\
\text { Centralised planning at headquarters } \\
\text { IVIRONMENT } \\
\text { Changes in business market, industry and technology } \\
\text { Resources to implement ICT project } \\
\text { Commitment from other departments to implement } \\
\text { SISP } \\
\text { Time needed to implement SISP plan }\end{array}$ \\
\hline $\begin{array}{l}\text { IMPACT/ } \\
\text { BENEFIT }\end{array}$ & $\begin{array}{l}\text { Work process efficiency } \\
\text { Effectiveness of business quality } \\
\text { Organisational performance } \\
\text { Cost effectiveness }\end{array}$ & $\begin{array}{l}\text { SISP implementation impact on work process } \\
\text { SISP implementation impact on business quality } \\
\text { SISP implementation impact on productivity } \\
\text { SISP implementation impact on cost }\end{array}$ \\
\hline
\end{tabular}

TABLE 5. Informant list

\begin{tabular}{|c|c|c|c|c|}
\hline & Code & Post & $\begin{array}{l}\text { Work experience } \\
\text { (year) }\end{array}$ & Experience in related field (year) \\
\hline 1 & I01 & Deputy director & 27 & $\begin{array}{l}\text { SISP implementation and development 2011-2011 } \\
\text { SISP implementation and development 2016-2020 } \\
\text { SISP development 2012-2015 }\end{array}$ \\
\hline 2 & I02 & Assistant director & 8 & SISP implementation and development 2016-2020 \\
\hline 3 & $\mathrm{I} 03$ & Assistant director & 10 & $\begin{array}{l}\text { SISP implementation and development 2011-2011 } \\
\text { SISP implementation and development 2016-2020 }\end{array}$ \\
\hline 4 & I04 & Assistant director & 8 & $\begin{array}{l}\text { SISP implementation and development 2011-2011 } \\
\text { SISP implementation and development 2016-2020 }\end{array}$ \\
\hline 5 & $\mathrm{I} 05$ & Assistant director & 7 & $\begin{array}{l}\text { SISP implementation and development 2011-2011 } \\
\text { SISP implementation and development 2016-2020 }\end{array}$ \\
\hline 6 & I06 & Assistant Officer & 12 & SISP implementation 2011-2015 \\
\hline 7 & I07 & Assistant Officer & 9 & SISP implementation 2011-2015 \\
\hline 8 & I08 & Assistant Officer & 13 & SISP implementation 2011-2015 \\
\hline 9 & I09 & Assistant Officer & 25 & $\begin{array}{l}\text { SISP implementation and development 2011-2011 } \\
\text { SISP implementation and development 2016-2020 } \\
\text { SISP development 2012-2015 }\end{array}$ \\
\hline 10 & $\mathrm{I} 10$ & Assistant Officer & 12 & SISP implementation 2011-2015 \\
\hline 11 & I11 & $\begin{array}{l}\text { Assistant Head of } \\
\text { Senior Director }\end{array}$ & 25 & $\begin{array}{l}\text { SISP development } \\
\text { ISP framework } \\
\text { SISP development 2016-2020 }\end{array}$ \\
\hline Tot & $1 \mathrm{~N}=11$ & & & \\
\hline
\end{tabular}

\section{RESULTS}

\section{SXSSO 2011-2015 SISP IMPLEMENTATION PRACTICE}

A total of 61 programmes were planned over a five-year duration of SISP implementation (2011 to 2015). Five planned ICT initiatives were infrastructure establishment and ICT 
security, comprehensive and integrated aplication development, competency enhancement and cultivation of ICT culture in service delivery, state ICT governance and enhancement of state community interaction. Four of the 18 projects under infrastructure establishment and ICT security failed owing to constraints related to finance and application features. Three of the four programmes under ICT interaction failed owing to financial problems. Eleven of 36 applications were not implemented owing to

a) Financial constraints,

b) Incapacity to identify information needs,

c) Application systems were not needed,

d) Decision from the state ICT steering committee to abandon the ICT programme/ project,

e) Projects were shifted under the federal government,

f) Time constraint to conduct a detailed study.

Thirty-six percent of ICT projects/ programmes were not implemented from 2011 to 2015 owing to constraint in resource allocation. In more than five years of SISP implementation duration, SXSSO revised SISP only once in 2015 and none for 2016-2020. Overall, SXSSO did not implement SISP based on the good practice.

\section{FACTORS INFLUENCING SISP IMPLEMENTATION}

We identified 25 factors influencing SISP implementation effectiveness (human $=9$; structure $=6$; environment $=6$ and technology $=4)($ Table 6$)$. We also identified nine additional factors, namely, user satisfaction, project management, governance, manpower, staff turnover, system and information quality, infrastructure capability and IS service support. The evaluation of SISP success and effectiveness can be viewed from alignment, analysis, collaboration, dynamic capability, effective IS and flexible infrastructure capability. The factors were analysed on the basis of human, organisational and technological factors.

\section{HUMAN}

Stakeholder Involvement All informants agreed on the importance of top, middle and operational management and implementers in ensuring that ICT project is implemented in accordance with organisational objective. High top management commitment is explained further in the top management measure under the organisational factor.

Knowledge and Skill All informants agreed on the importance of knowledge and skill in ensuring successful SISP implementation as most applications were developed in house. An incompetent officer required time to master and understand the programming language, resulting in project delay. The latter subequently resulted in user dissatisfaction. Informant 4 stated that despite their attendance to trainings, they failed to apply the knowledge completely owing to the difference in the training and actual environment. An officer required specific training based on actual agency requirement.

Educational Development $\quad$ SISP implementation indirectly improved staff knowledge. However, this condition depends on the interest and advocacy of the IT head department to cultivate the culture (Informant 1). Most staff were comfortable in using the old method. Therefore, instruction and enforcement of IT application from the head department is important to achieve optimal use of IT infrastructure, such as E-mail and WiFi, that eventually becomes a culture (Informant 3). Barriers to ICT culture include the lack of IT interest, change resistance from senior officer and lack of motivation and encouragement from superior. In general, the 
impact of educational development on staff from the SISP implementation in this agency is insignificant.

TABLE 6. Factors influencing agency SISP implementation Effectiveness

\begin{tabular}{|c|c|c|c|c|}
\hline Dimension & & Factor & Literature & Case study \\
\hline \multirow[t]{9}{*}{ Human } & 1 & Involvement and commitment & 1 & 1 \\
\hline & 2 & Knowledge and skill & l & / \\
\hline & 3 & Educational development & l & / \\
\hline & 4 & Implementation strategy & / & / \\
\hline & 5 & IT-business relationship & l & / \\
\hline & 6 & Motivation & l & / \\
\hline & 7 & Training & / & / \\
\hline & 8 & User satisfaction & & / \\
\hline & 9 & Project Management & & / \\
\hline \multirow[t]{14}{*}{ Organisation } & & Structure & & \\
\hline & 10 & Organisational readiness & / & / \\
\hline & 11 & Top management support & / & 1 \\
\hline & 12 & Leadership & / & / \\
\hline & 13 & Business and IT change & 1 & / \\
\hline & 14 & Governance & ( & / \\
\hline & 15 & Manpower & & / \\
\hline & 16 & $\begin{array}{l}\text { Environment } \\
\text { Understanding in business trend }\end{array}$ & 1 & 1 \\
\hline & 17 & Communication and knowledge & 1 & / \\
\hline & & $\begin{array}{l}\text { sharing between business and IT } \\
\text { sector }\end{array}$ & & \\
\hline & 18 & Resource allocation & / & / \\
\hline & 19 & Organisational commitment & / & / \\
\hline & 20 & Workload & / & / \\
\hline & 21 & Staff turnover & & / \\
\hline \multirow[t]{4}{*}{ Technology } & 22 & System quality & & / \\
\hline & 23 & Information quality & & / \\
\hline & 24 & Infrastructure capability & & / \\
\hline & 25 & IS service support & & 1 \\
\hline
\end{tabular}

Implementation Strategy A champion is one of the effective implementation project strategies for smooth information dissemination and communication. System requirements are normally acquired from the head unit, but their high turnover affects system requirement owing to the subsequent requirement differences. Therefore, a champion should be appointed among those who possess knowledge and competency in a work process to avoid constant requirement changes. The system development team interacted directly with the champion to obtain feedback and system requirement. Apart from the champion, project change requires proper management. During system development, the IT staff explained the system process that was agreed upon and understood by the user. However, the user refused to utilise the system after its handover as it failed to fulfill their requirements owing to the changes made by different individuals in charge at different project phases. From the management perspective, achievement of organisational mission requires good skills and planning. The planned strategy is effective if it is mapped in accordance with the strategic plan. An organisational objective can be achieved if officer and staff play their roles in implementing the strategy. Moreover, a project should be evaluated on the basis of its priority in terms of impact and financial budget. A project must also be monitored and managed according to the triple constraints, namely, resources, schedule and quality. All informants agreed on three critical skills of a project manager, namely, personnel, project and technical management. ICT projects were developed 
and managed by a responsible and experienced officer, instead of a project manager with Project Management certification, such as PRINCE 2 or PMBOK. Organised and strong project management positively affects SISP implementation.

Business and IT Relationship Business and IT Relationship in SISP implementation was generally unsatisfactory based on the project and its leader (Informants 1 and 2). Both IT and business officers should understand their roles and responsibilities. However, most business officers failed to commit as expected. In addition, the poor relationship affected SISP implementation owing to inadequate and constant changes in information requirement (Informant 6).

Motivation Staff turnover was linked to knowledge and skill and training. Turnover among technical, skilled and semi-skilled staff and subject matter expert results in knowledge drain (Informant 5). Staff turnover indirectly lowered the motivation among other staff to implement SISP because of the need to adapt to new staff working methods and achieve understanding among team members.

Training Related skill among implementer officers is lacking. Requirement analysis on needed training must be conducted 'in a smaller group to ensure adequate skill and subsequently the ability to implement system completely' (Informant 11). All informants agreed that a technical training programme can reduce the current problem in system development and highly improve overall SISP implementation. Moreover, an ongoing training programme on related application is needed to enhance its application.

User Satisfaction User satisfaction can be measured from developer and user's view. Not all implementers understood the importance and purpose of SISP. They only implemented the planned project without engaging directly in the ICT strategic planning process. Informant 11 argued that all organisational entities comprising top, middle and operational management; users and other stakeholders must be involved in implementing SISP. In addition, its details must be disseminated to all state public servants so that organisational mission can be understood and shared, considering SISP purpose as a reference and authorised source for implementing a project. User satisfaction is essential to justify the success or failure of an ICT project implementation.

\section{ORGANISATIONAL STRUCTURE}

Organisational Readiness Some of the projects were not implemented as scheduled owing to problems related to politics, misalignment of system requirement with head department needs, incompetent implementer officer, user inability to identify their preferred system requirement and constant change requirement caused by staff turnover. According to Informant 5 , agency was unprepared to implement the planned project because of its incapacity to identify relevant information. The project delay resulted on rework and wasted resources.

Top Management Support All informants agreed on the importance of top management support in SISP implementation. Top management support includes a two-way communication between management and staff, approval of financial resource allocation and provision of sufficient manpower. SXSSO has no problems with this factor in implementing ICT project. For example, Informant 1 mentioned top management support on SISP implementation and budget approval as they realised the importance of SISP in enabling SXSSO to achieve its vision. 
Leadership All informants agreed that leadership with vision and IT savy positively affect ICT planning implementation. The top management team, particularly the state secretary, was passionate with IT as he was aware that SXSSO required efficient ICT that can provide updated, accessible and accurate information for the public (Informants 1 and 2).

\section{ENVIRONMENT}

Understanding in Business Trend and IT Public agencies are moving towards the current technology and business trend. Many online and mobile applications have been developed to fulfill stakeholder and user needs. Social network sites, such as Facebook and Twitter, became a platform for an agency to communicate with the public. All informants agreed on the influence of understanding business trend and IT on SISP implementation.

Communication and Knowledge Sharing Between Business and IT Sector According to Informants 1 and 2, communication and knowledge sharing between business and IT sector was generally unsatifactory and ineffective as all implemented ICT programmes were not highly accepted. For example, most participants for the Technology Update Programme were among the IT staff/ officers compared with those of business. Many staff members resisted and were not interested in IT (Informant 4). Efforts to increase awareness among staff were not fruitful (Informant 6) possibly owing to the unconvincing effort in informing the potential importance and benefit of the programme.

Financial Resource The approved budget was insufficient to implement the entire ICT project owing to increased ICT infrastructure cost (Informant 2) and currency exchange (Informant 4). Financial allocation priority towards ICT project strongly affects the public sector and its people.

Organisational Commitment

Organisational commitment involving all management levels and business departments is important in ensuring that ICT project is implemented in accordance with organisational objective. The informants were very satisfied with the commitment from top management. According to Informants 1 and 11, top management collaborated by expressing their requirements and preferences during the planning process and continously monitored the ICT project that had impact on the public. Top management also engaged in determining human resource allocation for implementation and budget approval. Middle managers must implement the planned strategy by ensuring that budget and human resources are managed properly whilst the operational unit implements the action plan. This process includes users as their commitment and collaboration are needed to ensure that applications are developed according to their requirements. According to Informant 1, some of the users did not provide complete and timely information on work process; they took time up to a few months, and the delay affected system development and the overall user. Organisational commitment from the department that owned the main ICT programme in SXSSO was satisfactory.

Workload All informants agreed on the challenge of implementing concurrent ICT projects. The conflicting deadlines resulted in the incapacity to implement a number of projects as the team had to spend time on other complex projects. 
Technology All informants shared similar views on the influence of IS service support on SISP implementation. Technical support includes maintenance of devices, such as notebook, desktop, tablet PC, printer and scanner and audio-visual equipment.

System Quality The good application system implementation improved system quality. Informants also agreed on these system features: quick response time, ease of use, accessiblilty and reduced process time and beaurocracy.

Information Quality The application system produced quality information and optimally improved information management and control. Information reliability was also improved owing to information timeliness and completeness.

Infrastructure Capability SXSSO had a flexible infrastructure that supports requirements in terms of compatibility among hardware, software and network.

\section{SISP IMPLEMENTATION PROBLEMS}

Control Mechanism of the Project Implementation The monitoring of SISP implementation is meant to ensure that ICT project is implemented as scheduled. The absence of this mechanism resulted in project delay and incapacity to inform its progress to related committee, including the steering and ICT committees.

Ad-Hoc Project Some of the ICT implemented programmes/ projects were not included in the SISP document. This situation resulted in the abandonment of ongoing or planned projects to give way to the ad-hoc project.

Governance Governance played an important role in project implementation but is missing in SXSSO. Informant 1 stated that a temporary committee was only setup during the SISP development process and was dismissed upon its completion. In the absence of a steering committee to monitor and control SISP implementation, the agency established a unit that is responsible to take early action on risky projects. A monitoring mechanism was underway to report ICT project progress to top management. The reporting of SISP progress would become an agenda in SXSSO ICT Steering Committee meeting, which also acted as a platform for a two-way interaction between top management and implementer team in discussing issues and problems arising during ICT project implementation.

Manpower SISP implementation required sufficient manpower, particularly for concurrent and conflicting project deadlines. This need pressured and burdened the SXSSO officers who were prone to conflict owing to imbalanced workload among team members and indvidual skills and unsatisfied members. Lack of manpower affected project implementation (Informants 9 and 6).

\section{EFFECTIVENESS OF SISP IMPLEMENTATION}

The effectiveness of SISP implementation agency can be measured in terms of organisational performance and cost. Staff and agency performance were increased upon SISP implementation in 2011-2015. Cost was also reduced owing to centralised system development. The alignment of IT with business indicated the effectivenss of SISP implementation. ICT projects developed over five years supported business objectives. Half of the informants stated that the current process during SISP development was not analysed comprehensively as not all stakeholders were involved during the brainstorming session. 
Comprehensive environmental analysis is a critical indicator to justify the effectiveness of SISP implementation.

Stakeholder and user collaborated closely in implementing SISP. IS and dynamic capability as well as staff skill, capability and knowledge were increased. SXSSO had an adequate and flexible infrastructure that managed compatibility among hardware, software and network. Based on the aforementioned indicators, SISP implementation positively affects SXSSO organisation. Table 7 shows the mapping of factor and SISP Effectiveness indicator.

TABLE 7. Impact/ benefit of SISP implementation

\begin{tabular}{lll}
\hline Factor & Effectiveness Indicator & Impact \\
\hline - Implementation strategy & Work process efficiency & positive \\
- Management Project & & \\
- Governance & & \\
- Leadership & & \\
- Organisational readiness & & \\
- Manpower & negative \\
- Motivation & & \\
- Staff turnover & Oriness effectiveness & positive \\
- Organisational commitment & & \\
- User satisfaction & positive \\
- Resource allocation & Cost effectiveness & positive \\
- IT-business relationship & IT-business Alignment & \\
- Business and IT change & Analysis & \\
- Understanding in business trend (market, & & \\
industry and technology) & & \\
- Top management support & & \\
- Communication and knowledge sharing & Collaboration & \\
- between business and IT sector & & positive \\
- Involvement and commitment & & \\
- System quality & Capability improvement & \\
- System service support & & \\
- Information & & \\
- Infrastructure capability & & \\
- Information quality & & \\
- Educational development & & \\
- Training & & \\
- Workload & & \\
- Knowledge and skill & & \\
\hline
\end{tabular}

\section{DISCUSSION}

Factors idenfied from the literature were validated from the case study, except the centralised planning. It does not affect SISP implementation as the ICT department is depending on state financial resources. SISP could not be implemented without active collaboration and participation from all stakeholders. The analysis of business and ICT environment required input and suggestion from all three management levels; project owner and user and SXSSO agencies. Problems require consideration and scrutiny to obtain a comprehensive analysis 
under SXSSO authority. Project team should be appointed from those who can provide appropriate response and understand the state aspiration and to avoid inaccurate analysis. The absence of top management during discussion required other initiatives, such as separate interview sessions, to gather their requirements and vision and to avoid the inclusion of ad-hoc project, ensuring project delivery as scheduled and avoiding additional work load and subsequent pressure. To minimise staff turnover problems, staff workload must be redistributed according to staff competency. An on-going multiple training level is needed to enhance staff competency, followed by trainings and their evaluation to assess the level of participant's skill and knowledge. Prior to staff turnover, an agency must transfer knowledge to avoid knowledge drain. Knowledge refers to skill, wisdom and tacit knowledge required to perform task and responsibility. Structured and systematic knowledge transfer enabled organisation to optimise its capability during implementation.

Organised good governance is a key to successful SISP implementation. The governance structure should consist of committees that can make decisions, establish team work and handle a technical support team critical for developing a clear guideline and work process. Potential risk must be identified and addressed earlier to minimise risk during project implementation. Workshops can be organised for all stakeholders to reduce culture gap, and changing management programme must be organised to improve awareness among them.

\section{CONCLUSION}

The study evaluated the level of SISP implementation at a public service agency. The identified factors can guide SISP practitioners, particularly Chief Information Officer, in managing SISP implementation and risk to avoid its failure. Although the study findings are limited to the SXSSO agency, the general and similar factors are applicable to and can be benchmarked by other public agencies. The study can be extended to different domains and SISP development process to evaluate the relationship between SISP development and implementation. Overall, the HOT-fit framework is applicable for evaluating the effectiveness of SISP implementation.

\section{ACKNOWLEDGMENT}

We greatly appreciate Public Service Department of Malaysia and Grand Impact Grant (DIP2016-033), Universiti Kebangsaan Malaysia for sponsoring this study.

\section{REFERENCES}

Al-Aboud, F.N. 2011. Strategic information systems planning: A brief review. International Journal of Computer Science and Network Security 11(5): 179-183.

Al-Ammary, J.H., Al-Doseri, S., Al-Blushi, Z., Al-Blushi, N. \& Aman, M. 2019. Strategic information systems planning in Kingdom of Bahrain: Factors and impact of adoption. International Journal of Business Information Systems 30(4): 387-410.

Alamri, S., Almutiri, N., Ballahmar, H. \& Zafar, A. 2016. Strategic Information system planning: A case study of a service delivery company. International Advanced Research Journal in Science, Engineering and Technology 3(5): 78-84.

Ali, R.H.R.M., Crump, B. \& Sudin, S. 2014. Strategic IS planning practices: A comparative study of Malaysia and New Zealand. Procedia - Social and Behavioral Sciences 164(August): 516-521.

Allio, M.K. 2012. Strategic dashboards: Designing and deploying them to improve implementation. Strategy \& Leadership 40(5): 24-31.

Amrollahi, A., Ghapanchi, A.H. \& Talaei-Khoei, A. 2013. A systematic literature review on 
strategic information systems planning: Insights from the past decade. Pacific Asia Journal of the Association for Information Systems 5(2): 39-66.

Arvidsson, V., Holmström, J. \& Lyytinen, K. 2014. Information systems use as strategy practice: A multi-dimensional view. Journal of Strategic Information Systems 23(1): 4561.

Awadallah, E.A. \& Allam, A. 2015. A critique of the balanced scorecard as a performance measurement tool. International Journal of Business and Social Science 6(7): 91-99.

Bermejo, P.H.de S. \& Zambalde, A.L. 2014. Using the BSC for Strategic planning of IT (Information Technology) in Brazilian organizations. Journal of Information Systems and Technology Management 11(2): 361-378.

Haron, H., Md Sabri, S. \& Zolkarnain, Z.N. 2013. A situational analysis of strategic information system planning in the context of a Malaysian SME. International Conference on Research and Innovation in Information Systems (ICRIIS 2013), 27-28 November, Kajang, Malaysia, 539-543.

Harun, H. \& Hashim, M.K. 2012. Problems in planning and implementing strategic information systems: Some evidence from Malaysian Government Agencies. International Journal of Research In Science \& Engineering 3(1): 21-27.

Harun, H. \& Hashim, M.K. 2017. Strategic information systems planning: A review of its concept, definitions and stages of development. International Journal of Research In Science \& Engineering 3(2): 432-441.

Hoque, M.R., Hossin, M.E. \& Khan, W. 2017. Strategic information systems planning (SISP) practices in health care sectors of Bangladesh. European Scientific Journal 12(6): 307321.

Ismail, N.A., Ali, R.H.R.M., Saat, R.M. \& Hsbollah, H.M. 2007. Strategic information systems planning in Malaysian public universities. Campus-Wide Information Systems 24(5): 331 341.

Kaplan, R. S. \& Norton, D. P. 1996. Using the Balanced Scorecard as a strategic management system. Harvard Business Review 74(1): 75-85.

Kelvin, O.O., Oghenetega, I. \& Jackson, A. 2012. A review of issues in information and communication technology (ICT) planning and implementation in academic libraries in Nigeria. Library Hi Tech News 29(8): 11-17.

Khani, N. 2010. Factors Moderating the Relationship between IS capabilities and strategic information system planning (SISP) Success. SSRN Electronic Journal(November): 1-5.

Klag, M. \& Langley, A. 2014. Critical junctures in strategic planning: Understanding failure to enable success. Organizational Dynamics 43(4): 274-283.

Lederer, A.L. \& Salmela, H. 1996. Towards a theory of strategic information systems planning. Journal of Strategic Information Systems 5(3):237-253

Manoharan, A., Melitski, J. \& Bromberg, D. 2015. State strategic information system plans. International Journal of Public Sector Management 28(3): 240-253.

Mirchandani, D.A. \& Lederer, A.L. 2014. The impact of core and infrastructure business activities on information systems planning and effectiveness. International Journal of Information Management 34(5): 622-633.

Mohdzaher M. \& Ward, J.M. 2007. A study of subsidiaries' views of information systems strategic planning in multinational organisations. The Journal of Strategic Information Systems 16(4): 324-352

Murby, L. \& Gould, S. 2005. Effective performance management with the Balanced Scorecard. London: Chartered Institute of Management Accountants. Available at https://www.cimaglobal.com/Documents/ImportedDocuments/Tech_rept_Effective_Perf ormance_Mgt_with_Balanced_Scd_July_2005.pdf

Okumus, F. 2003. A framework to implement strategies in organizations. Management 
Decision 41(9): 871-882.

Pita, Z., Cheong, F. \& Corbitt, B. 2014. Strategic information systems planning (SISP). International Journal of Strategic Decision Sciences 1: 28-61.

Segars, A.H. \& Grover, V. 1998. Strategic information systems planning success: An investigation of the construct and its measurement. MIS Quarterly 22(2):139-163.

Turban, E., Pollard, C. \& Wood, G. 2018. Information Technology for Management: OnDemand Strategies for Performance, Growth and Sustainability. 11th edition. Hoboken: Wiley.

Wahyudin, A. \& Hasibuan, Z. 2015. Research classification in strategic information system planning development: A critical review. International Conference on Science in Information Technology (ICSITech), 27-28 October, Yogyakarta, Indonesia, 287-292.

Yang, J., Pita, Z. \& Singh, M. 2013. A conceptual framework for assessing strategic information systems planning (SISP) success in the current dynamic environments. 24th Australasian Conference on Information Systems 4-6 Dec, Melbourne, Australia.

Yusof, M.M., Paul, R.J. \& Stergioulas, L.K. 2006. Towards a framework for health information systems evaluation. Proceeding of the 39th Hawaii International Conferences on System Sciences. 4-7 January. Kauai, Hawaii, USA, 1-10.

Yusof, MM., Stergioulas, L. and Zugic, J. 2007. Health information systems adoption: findings from a systematic review. in: Kuhn, KA., Warren, JR. and Leong, T. eds. MEDINFO 2007. IOS Press (129): 262-266.

Yusof, M.M., Papazafeiropoulou, A., Paul, R.J. \& Stergioulas, L.K. 2008. Investigating evaluation frameworks for health information systems. International Journal of Medical Informatics 84(7): 377-385.

Yusof, M.M. 2015. A case study evaluation of a critical care information system adoption using the socio-technical and fit approach. International Journal of Medical Informatics 84(7): 486-499.

Zubovic, A., Pita, Z. \& Khan, S. 2014. A framework for investigating the impact of information systems capability on strategic information systems planning outcomes. The 18th Pacific Asia Conference on Information Systems (PACIS 2014) Proceedings, 24-28 June, Chengdu, China, 317.

Sukhaila Angsor

Malaysian Royal Custom Department

MKN Embassy Techzone, Cyber 4

63000 Cyberjaya, Selangor, MALAYSIA.

E-Mail: sukhailaangsor@gmail.com

Maryati Mohd Yusof (corresponding author)

Faculty of Information Science and Technology

Universiti Kebangsaan Malaysia

43600 UKM Bangi, Selangor, MALAYSIA.

E-Mail: Maryati.Yusof@ukm.edu.my 